\title{
Towards a New Political Economy of Climate Change and Development
}

\author{
Thomas Tanner and Jeremy Allouche*
}

\begin{abstract}
In this article, the authors propose a new political economy of climate change and development in which explicit attention is given to the way that ideas, power and resources are conceptualised, negotiated and implemented by different groups at different scales. The climate change and development interface warrants such attention because of its importance to achieving sustainable poverty reduction outcomes, cross-sectoral nature, urgency and rapid emergence of international resource transfers, initiatives and governance architectures, and the frequent assumption of linear policymaking and apolitical, techno-managerial solutions to the climate change challenge.
\end{abstract}

\begin{abstract}
1 Introduction
Despite the inherently political nature of international negotiations on climate change, much of the theory, debate, evidence-gathering and implementation linking climate change and development assume a largely apolitical and linear policy process. As the issue continues to dominate agendas, it is timely to propose a new political economy of climate change and development in which explicit attention is given to the way that ideas, power and resources are conceptualised, negotiated and implemented by different groups at different scales.
\end{abstract}

Climate change has become one of the defining contemporary international development issues. Poverty and human development have been linked with both the limiting of atmospheric greenhouse gas (GHG) concentrations to levels that avoid dangerous climate change ('mitigation') and the adjustment of human and natural systems to actual or expected climate stimuli or their effects ('adaptation') (McCarthy et al. 2001). Recently, the poverty, environment and development community has been instrumental in shifting the international focus from mitigation towards a more balanced approach that recognises adaptation priorities. This recognises the pressing underlying need for mitigation, but also the need for adaptation, given the realities of coping with prevailing climate-related impacts and lock-in from historic emissions to some change, no matter what level of mitigation is achieved.

Adaptation and development is situated within existing poverty levels and income inequalities, with commentators highlighting the unequal distribution of the impacts of climate change and the resulting inequity and unfairness given that poor people globally have contributed least to the problem (Adger et al. 2006; Kates 2000; Tol et al. 2004; Tanner and Mitchell 2008). At the same time, with 1.4 billion people still without access to electricity, the move to low carbon development pathways has engaged those interested in energy and poverty, both centralised and decentralised, as well as other poverty-centred aspects of mitigation, including forestry and agriculture (IEA et al. 2010; Nabuurs et al. 2007; Smith et al. 2007). As a result, there has been unprecedented growth in projects, programmes and policies that link climate change and development (McGray et al. 2007; UN-Energy 2010). These have been driven particularly by United Nations Framework Convention on Climate Change (UNFGGG) processes and international development agencies.

We argue here that in determining a balance between effectiveness, efficiency and equity, climate change initiatives must explicitly recognise the political economy of their inputs, processes and outcomes. Political economy is 
defined here as the processes by which ideas, power and resources are conceptualised, negotiated and implemented by different groups at different scales. In applying this definition to climate change and development, we seek to broaden the analysis from state-focused environmental politics to encompass interactions between the state and non-state actors. This is more familiar to strands of political ecology (Bryant and Bailey 1997) but we also seek to highlight the importance of ideas, ideology and power in determining these inter-relationships (Bourdieu 1977; Clapp and Dauvergne 2005).

The articles in this issue of the IDS Bulletin provide an empirical examination of these processes, particularly in influencing international initiatives and their translation across scales and the way that research and scientific information are used in the process. This framing article provides a rationale for greater understanding of the political economy of climate change, a suggested conceptual approach, and a summary of the findings presented in this IDS Bulletin. In doing so, it provides an evidence base to support the call for greater attention to the political economy of climate change.

\section{Why do we need a new political economy of climate change?}

The pressing need to consider political economy dimensions of climate change and development linkages is founded upon four key issues. First, the complexity of its political economy is increased by the cross-sectoral nature of the issue, with implications across the development spectrum, from climate-sensitive and emissionssensitive sectors to finance and governance. Second, climate change has been mainly problematised and tackled as a global issue, resulting in globally-led governance approaches, which may not provide sufficient flexibility for specific national or sub-national conditions. Third, the expectation and reality of growing climate change finance changes incentive structures and rent-seeking behaviours, as well as raising wider questions about the conceptual drivers and governance of resource transfer. Fourth, we argue that a political economy approach is crucial in unpacking assumptions about tackling climate change that rely on a linear apolitical view of the policy process and tend to frame solutions in technical and managerial terms. Finally, there are significant differences in ideological worldviews regarding responding to climate change that affect decisions as to how it should be tackled.

The rationale for renewed efforts to understand the political economy of climate change and development is based on some of the specific characteristics of the climate change issue but also its importance in achieving sustained poverty reduction outcomes. This is underpinned by the cross-sectoral nature of the climate change problem and its solutions: Multiple facets of development are affected by its impacts, while reducing emissions cuts across electricity generation, transportation, domestic and commercial use, agriculture and industrial emissions. As a result, our success in tackling the causes and impacts of climate change will have a significant bearing on our ability to reduce poverty sustainably (Stern 2006; UNDP 2007).

Climate change issues do not neatly fit into a specific sector. This cross-cutting nature of climate change means that there are frequent calls to integrate or mainstream the issue across other areas of development policy and practice (Reid et al. 2003; OECD 2009). As a result, there are multiple scales, high diversity and complexity in its governance, its finance, and its actors (Rabe 2007). While there is a case for understanding political economy processes in any development arena, the interaction of these facets result in political processes with multiple and overlapping conceptualisation, negotiation and governance issues.

As a global problem with a growing international architecture, climate change debates and initiatives have tended to be driven from the global scale. The development of a global agreement under the UNFCGC to follow the first commitment period of the Kyoto Protocol beyond 2012 has seen a massive stepping up of political action. For environment and development activists, this has been characterised by attention to issues of equity and global environmental justice in the creation of a fair international regime that would simultaneously prevent dangerous climate change and protect people's right to move out of poverty. For those 'Annex 1' industrialised countries, most of whom have emissions targets under the Kyoto agreement, the focus has been to ensure that a future regime brings in a wider 
range of countries, particularly those with large shares in the overall global emissions burden. Within these contexts, climate change is presented both as a global crisis that threatens to derail recent progress in poverty reduction and as an opportunity to engage and stimulate the dominant mode of capitalist development (Oxfam 2009a; GHF 2009; LaFleur et al. 2008; Newell and Paterson 2010).

Analyses of the political economy of climate change have tended to focus on either:

- The international politics of climate change (Dessler and Parson 2006; Luterbacher and Sprinz 2001), and in particular the different perception and perspective of the different governments in the global North and South. This debate has raised important issues from an international political economy perspective around global environmental justice, rights and compensation (Jamieson 2001; Adger et al. 2006; Roberts and Parks 2007; Okereke 2008a,b).

- The role and business strategy of global corporate actors in the international politics and economy of climate change, for example on the responses of firms in the USA and European oil and automobile industries to control emissions of greenhouse gases (Levy and Kolk 2002); or the positioning of the financial sector and investors to benefit from the creation of carbon markets as carbon traders (such as Eco-securities and Climate Care), or investors (such as JP Morgan and Barclays) (Newell and Paterson 2010). These debates have highlighted from an international political economy perspective, the importance of neo-Gramscian approaches in understanding hegemony, ideology and power (Levy and Newell 2002).

These strands of analysis, while revealing of the inherently political nature of international negotiations and private sector engagement, do not tackle an important element of the climate change and development arena, namely the formulation and translation of international initiatives to national and sub-national policy contexts. This is at the core of our suggested new political economy of climate change and development, and is increasingly needed given the emergence and expectation of growing streams of climate initiatives and finance.
The Cancun Conference of the Parties to the UNFCGC in 2010 committed significant sums of money from industrialised countries to support adaptation, mitigation and related technology cooperation in developing countries: US\$30 billion in 'fast start finance' up to 2012 and the intention to raise US $\$ 100$ billion in long-term funds by 2020. There have been calls, particularly from developing country governments at the UNFCGC negotiations for this money to be committed entirely through the Convention bodies, and this is reflected in the decision at Cancun to design a Green Climate Fund (Bird et al. 2011). However, at least in the short term, fast start finance will flow through a range of channels including bilateral and multilateral official development assistance, the Global Environment Facility (GEF) and the UNFCGC, including the Adaptation Fund (see Harmeling and Kaloga, this IDS Bulletin).

In addition, a growing number of public funds are already stimulating greater work on climate change in developing countries, including the Pilot Program for Climate Resilience (PPCR), administered by the World Bank through the Climate Investment Funds (see Seballos and Kreft, this IDS Bulletin). The PPCR aims to create an integrated, scaled-up approach to climate change adaptation in a number of (initially eight) participating low-income countries, preparing them for future adaptation finance flows such as those emerging from the UNFCGC processes. In addition, the emerging schemes around Reducing Emissions from Deforestation and Degradation (REDD+) will be an important stimulus to, and source of funding for, both adaptation to and mitigation of climate change (see Hiraldo and Tanner, this IDS Bulletin). REDD+ schemes also engage with private sector financial flows, playing a growing role in the global carbon economy alongside the Clean Development Mechanism, Joint Implementation and the voluntary emissions offset market.

Climate change finance in developing countries also has the potential to transform traditional aid modalities. This comes down to differential interpretations by developing and industrialised countries of the principle of 'common but differentiated responsibilities' enshrined in the climate change Convention (Okereke 2008b). Rather than being based on capability, altruism, 
charity or political interest, climate change resource transfers are increasingly framed by developing countries and campaign organisations on the basis of equity and 'climate justice'. In doing so, they call on industrialised countries not only for leadership in cutting emissions, but also for resource transfers on the basis of the culpability for damages caused and in addition to existing commitments for official development assistance (Abdullah et al. 2009; Oxfam 2009b). The corollary to this argument is that different governance structures are required for climate change finance that gives greater control to developing countries and breaks traditional donor-recipient relationships.

Despite the slow progress of the UNFCCG negotiations, the development of financing mechanisms is characterised by a sense of urgency and innovation. Both the expectation and development of these resource flows and their governance are influenced by competing ideologies and driven by new incentive structures and potential for rent capture, both in developing countries and internationally. These financial flows and pathways are already changing the nature of the development arena, yet there remains limited understanding of the political economy processes that underpin them. These will be crucial determinants of the successful creation of low carbon and climate resilient development, through private sector flows, new international financing mechanisms and existing aid flows.

A political economy approach will also help to unpack technocentric and managerial approaches to tackling climate change that regard these processes in apolitical terms. To date, much of the analysis, policy prescription and action have centred on assumptions around standardised governance and planning systems, linear policy processes, readily transferable technology, economic rationality, and the ability of science and technology to overcome resource gaps (Leach et al. 2010). This has been particularly pronounced in the climate change arena because of the dominance of science as a policy driver, leading to a bias towards technology-led solutions (Klein et al. 2007). Taking a political economy approach will improve understanding of the complexity of decision-making and policy processes on climate change, differences in governance and planning systems, the power relations mediating competing claims over resources, and the contextual conditions for enabling the adoption of technology. As outlined in the next section, the wide-ranging differences in ideological worldviews also influence responses to climate change (Carvalho 2007), with some actors calling for the commodification of environmental flows and services as a response, others in favour of new regulatory regimes, and others focusing on norms, rights and global environmental justice.

Research and practice therefore needs to go beyond the dominant political process which represents climate change as a global problem requiring global solutions. In particular, greater attention is required to the translation of global governance processes to national and subnational governance processes. This requires examination of how climate change initiatives are conceptualised, negotiated and implemented at the global level and then reconceptualised, renegotiated and implemented at the national and sub-national levels, as well as the interaction between these levels.

\section{A conceptual and analytical framework}

There is an increasing number of political economy tools available, particularly those formulated by international development agencies (DFID 2009; European Commission 2008; Sida 2006; World Bank 2004, 2009).

However, we argue that it is necessary to develop a new conceptual and methodological framework for analysing the political economy of climate change. In the development context, political economy analysis have been applied and developed at three principal levels (World Bank 2009: 23-4):

- Country-level analysis, which seeks to capture the overall governance situation and the main political economy drivers;

- Sector and thematic analysis, which focuses on specific areas and may cover an entire value chain;

- Problem-driven analysis, which focuses on specific projects and/or policy decisions.

Recent guidance from DFID on political economy analysis recognised the need to understand the impact of regional or global drivers on domestic change processes given the increasingly interdependent nature of the current global system (DFID 2009). 


\begin{tabular}{|c|c|c|}
\hline Issue & Dominant approach & New political economy \\
\hline Policy process & Linear, informed by evidence & Complex, informed by ideology, actors and power relations \\
\hline Dominant scale & Global and inter-state & Translation of international to national and sub-national level \\
\hline $\begin{array}{l}\text { Climate change science } \\
\text { and research }\end{array}$ & $\begin{array}{l}\text { Role of objective science in } \\
\text { informing policy }\end{array}$ & Social construction of science and driving narratives \\
\hline Scarcity and poverty & Distributional outcomes & Political processes mediating competing claims for resources \\
\hline Decision-making & $\begin{array}{l}\text { Collective action, rational } \\
\text { choice and rent seeking }\end{array}$ & Ideological drivers and incentives, power relations \\
\hline
\end{tabular}

Nevertheless, current tools for political economy analysis do not integrate these global dynamics, which makes it difficult to understand how political institutions, the political environment, and the economic system interact at the national level. The specific institutional architecture underpinning climate change and development internationally and nationally should therefore be the focus of political economy analysis for climate change and development. This overview article focuses on recommendations for those developing and implementing climate change initiatives and future research priorities.

We develop here a new political economy approach that analyses policy processes and outcomes in terms of ideas, power and resources to frame the articles in this IDS Bulletin. This goes beyond dominant approaches to analysis of climate change initiatives, as highlighted in Table 1. This includes the model of the policy process, attention to scalar issues beyond the global, the social construction of science and importance of driving narratives, a focus on processes mediating resource distributions and the inclusion of power and ideology.

We seek to go beyond orthodox international political economy analyses, which have been limited to material factors and have ignored how ideas and ideologies also determine policy outcomes (Barnett and Finnemore 2004). These ideological framings often become part of narratives that are supported by particular actors, networks and institutions and justify a particular set of actions (Leach et al. 2010). For example, Clapp and Dauvergne (2005) define broad sets of environmental ideologies as: the market liberals, who 'underscore the benefits and dynamics of free trade and technology', the institutionalists, who 'emphasize the need for stronger global institutions and norms', the bioenvironmentalists, who 'stress the limits of earth to support life' and social greens who 'see social and political problems as inseparable'.

These different worldviews enable us to provide a link between different levels of analysis at the global, national and local level. Although idealised views, these provide important analytical tools in understanding convergences, coalitions and divergences in the global and national political economy of climate change. Our assumption is that market liberalism will be the most powerful ideology in terms of structural power. As highlighted by Bernstein (2001) and Okereke (2008a) among others, global environmental governance is dominated by the 'liberal environmentalism compromise', as embedded in the 1992 Rio Earth Summit and its corollaries. This refers to the way in which the concept of sustainability was transformed into a set of technical understandings that purged it of its radical elements so as to do as little harm as possible to orthodox ideas of economic development.

The major difficulty is to provide an analytical distinction between ideas and interests as determinants of policy (Campbell 1998) and our focus will be on the intersection between ideas and power. There is a strong correlation between the concept of power and ideas. Power can in some instances be used as an all encompassing concept, which includes ideas and ideologies. As Bourdieu (1977: 165) noted:

The theory of knowledge is a dimension of political theory because the specifically symbolic power to impose the principles of the 


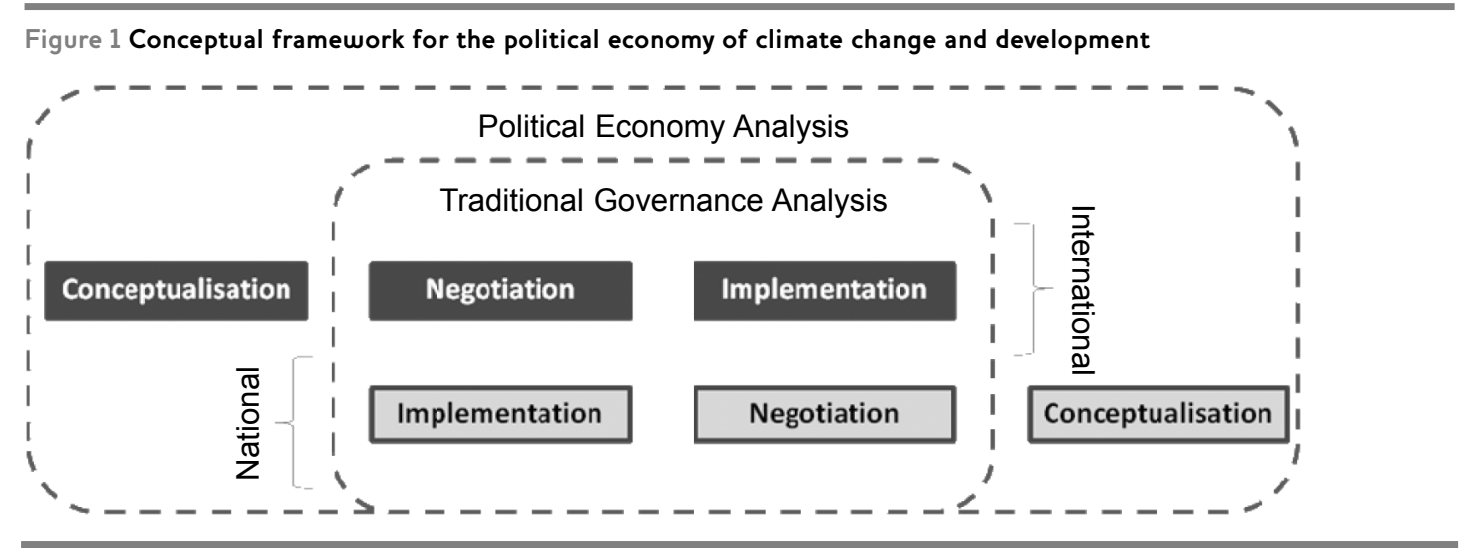

construction of reality - in particular, social reality - is a major dimension of political power.

Power can be seen as both relational and structural (relational being the ability of actors to compel others to change their policies, while structural power refers to authority, or 'power over' outcomes in global frameworks of security, finance, production and knowledge relationships). Strange (1988) argues that it is the less visible structural power, informing the agenda that needs to be examined for a meaningful analysis of the international political economy.

Many of the articles in this IDS Bulletin suggest a disconnect between international initiatives, national implementation processes and the space for public consultation. This disconnect is usually analysed as a governance gap, essentially the failure of national agencies to implement programmes due to the lack of technical capacity, resource constraints or political will (Cammack 2007). Instead, we argue that one should expect the implementation outcomes at the national level to be differentiated, since the national space reflects an additional layer of renegotiation. Responses to climate change need to be understood through a political economy framework that takes into account ideas and ideology and different scales. Previous governance analyses have focused largely on institutions, power and capacity building, rather than political ideological processes embedded in the governance of climate change and development (Béland 2009).

Most global governance analyses have described global processes as a collective action solution emerging out of a shared concern for improved governance of common goods (in our case, climate change). These previous analyses ignore the different aspects of power in negotiation processes, namely imposition, domination, structural determination or cultural hegemony (on the failure to integrate power in global governance analysis, see Barnett and Duvall 2005). Our conceptual framework of the political economy of climate change and development is represented in Figure 1.

This is an analytical framework that distinguishes between different elements in the policy process. Our framework of analysis breaks the political economy of climate change into six sets of analytical areas involving the conceptualisation, negotiation and implementation of climate change initiatives at both international and national levels. It explicitly recognises the inphases between international and national implementation. The programmes are translated and debated at the national level, providing spaces for negotiation and interpretation between civil society, NGOs, private actors, and the different ministries in government. While there are many examples of bottom-up initiatives, especially around community-based adaptation and decentralised energy, this framework emphasises the primacy of global politics in policymaking in the political economy of climate change and development.

While providing an analytical starting point, two major issues should be recognised. First, this framework does not represent a linear transition from conceptualisation to implementation (Keeley and Scoones 2003). Rather, it provides an analytical framework to deconstruct the policy dynamics around conceptualisation, negotiation and implementation. Second, the boundaries 
between the international and national dynamics are permeable, representing the fluidity between these different levels. National dynamics are often key influences on international processes and vice versa. For example, writing on the REDD agenda in Brazil, Shankland and Hasenclever (this IDS Bulletin) show how preparation for global forums and events provided a powerful driver for domestic negotiation with political parties, NGOs and civil society organisations.

Across these analytical areas, the framework analyses the interplay between the three lenses of ideas, power and resources in the political economy of climate change and development. While the boundaries between these three lenses are blurred, our hypothesis is that each of these concepts tends to be predominant at one stage of the policy process of the political economy of climate change. Ideas and ideologies are predominant in the conceptualisation phase, power in the negotiation phase and resources, institutional capacity and governance in the implementation phase.

\section{Contributions of a new political economy of climate change and development}

The conceptual framework presented above helps to break down different dimensions of political economy and tools for their analysis around climate change and development. The articles in this IDS Bulletin provide examples of how elements of these concepts can be used to capture and frame knowledge in case-specific contexts. These are organised around three themes. The first four articles (summarised here in section 4.1) analyse the political economy elements of international climate change and development policy processes and initiatives. Five further articles then reflect on the translation of these processes at the national and sub-national level and examine how international climate change initiatives processes are transformed through new conceptualisations and renegotiation (summarised here in section 4.2). The last three articles (summarised here in section 4.3) seek to understand and inform policy spaces for change by looking at how research inputs and stakeholder engagement can inform policy processes around climate change and development.

\subsection{International initiatives}

To date, there has been significant analytical attention to climate change at the international level, predominantly on aspects of the UNFCGC negotiations and inter-state politics (see, e.g. Luterbacher and Sprinz 2001; Yamin and Depledge 2004; Roberts and Parks 2007; Park et al. 2008). The first set of articles in this IDS Bulletin examines the political economy of international climate change and development initiatives. These stem both directly from the UNFCCG, as in the case of the Adaptation Fund and REDD, and indirectly, such as the World Bank's Pilot Program for Climate Resilience (PPCR) and broader global carbon market. These articles reveal the way that international initiatives are determined not by objective scientific evidence but by the dynamics of ideas, interests and power relations at play across different actors in international processes. They also raise important issues for the future of international climate initiatives, particularly the development of the Green Climate Fund agreed in Cancun in 2010.

Richard Klein and Annett Möhner provide a critique of the idea that objective science can lead decision-making on climate change finance. They trace the history and contemporary debates around defining which countries should be prioritised based on their vulnerability to climate change impacts. Analysis of the Global Climate Change Alliance, the PPCR and the Adaptation Fund reveals that vulnerability and prioritisation are inconsistent. The determination of vulnerability varies from one scheme to another and is both politically and scientifically ambiguous, reflecting 'ontologically localised' science that is specific to types of phenomena and its location (Aronson et al. 1994: 153). This supports a broader conclusion reflected across this IDS Bulletin and in the wider literature, around the institutional nature and sociopolitical construction of science linking climate change and development (Dessler and Parson 2006; Schneider 2010).

The political economy of the Adaptation Fund under the UNFGCG is further examined by Sven Harmeling and Alpha Kaloga in their article. The Adaptation Fund is innovative in a number of ways. It operates under the authority of the UNFCGC country Parties and unlike other UNFCGC funds, its resources are not based on voluntary donation. Instead, they are generated from a levy on the proceeds of transactions made under the Glean Development Mechanism (CDM), under which industrialised countries can meet part of their Kyoto Protocol targets through 
emission reduction projects in developing countries. Governance of the fund by the Adaptation Fund Board differs from other donordriven funds in its transparency and majority developing country membership. This structure also allows for implementation via direct access of funds rather than through a UN implementing agency.

The negotiation of the Fund's operating modalities reflects the international institutional competition familiar to other climate change initiatives, particularly around the respective roles of the Global Environment Facility (GEF) and the World Bank. The creation of a separate governance structure was justified by developing countries by the special nature of the Fund itself. Despite this, the Adaptation Fund remains poorly financed, given its scope. The authors suggest that this is due to it being a new modality, through a new set of environmental institutions, and designed to stand alone from voluntary contributions. The environment ministry and project-based Adaptation Fund implementation process also runs counter to the ideological narrative popular with international development donor agencies. This promotes mainstreaming by embedding adaptation in government development planning processes and encouraging a ministry with a broad mandate, such as planning or finance, to be fully involved (AfDB et al. 2003: XI).

This mainstreaming narrative is examined by Fran Seballos and Sönke Kreft's article on the formulation and governance of the World Bank's PPCR. The article provides a framing analysis within which subsequent country case studies on Mozambique, Nepal and Bangladesh contained in this IDS Bulletin can be situated. They suggest that the programme combines the validation and reinforcement of this ideology with the sense of urgency in implementing adaptation measures and the positioning of the World Bank Group and multilateral development banks on the climate finance stage. In using the structures of international financing institutions as implementing agencies especially by bringing loanbased finance into the picture, this fund challenges many principles of the UNFGCG process.

The presence of competing ideologies and narratives are also important components of the process of negotiating international architecture and norms around REDD+. Rocío Hiraldo and Thomas Tanner's examination of different ideological worldviews frames the proposals, issues and negotiation around reducing emissions from deforestation, reforestation and land degradation. The dominant market-liberal ideology that frames proposals around market mechanisms is linked to Annexe I country concerns about the need to find low-cost REDD+ funding modalities, while international institutional competition can also be witnessed in the support to different proposed regimes. They also critique the voice of forest-dwelling indigenous movements within the REDD+ negotiations, arguing that the invited spaces open to observer groups under the UNFCCG are created by more powerful actors in order to increase the legitimacy of their proposals.

The issue of power and inclusion within the processes of negotiating and implementing climate change and development initiatives is reflected across all of the articles in this IDS Bulletin. Besides simple attempts to capture the emerging rents from these initiatives, three inter-related causal factors can be distinguished.

First, the sense of urgency to plan, develop and implement initiatives provides a disincentive to more complex and inclusive processes of dialogue and negotiation. As discussed further below, one consequence is that more powerful voices are readily able to articulate a strong framing narrative or set of narratives to which others are only able to make incremental changes. For the PPCR for example, one result has been the exclusion of civil society, national governments and other donors, from the processes determining where and how the finance is implemented, and who manages that implementation.

Second, the existing channels for accountability and inclusion are often more issue or sector driven, while climate change initiatives cut across multiple sectors and issues, particularly in the divide between adaptation and mitigation approaches. Peter Newell et al.'s article notes that despite this overlap, the renewable energy sector in India has benefited from its strategic management being designated to a single Ministry, avoiding some of the common governance problems of overlapping functions and duplicated mandates across government. Finally, the predominant vision of tackling 
climate change through international institutions and national governments necessarily limits the opportunity for broader engagement. We argue that is not only because they are underpinned by the inter-governmental process of the UNFCCG but also due to the dominance of an ideological framing around mainstreaming of climate change into development processes that focuses attention more on links within government and less with those outside. Equally, the process of internationalising climate change initiatives and the consequent concentration of climate finance delivery in structures outside the country architecture may retain power in spaces beyond the influence of the country government and civil society actors, as noted by Seballos and Kreft in their article on the PPCR.

\subsection{Translating international initiatives across scales}

As illustrated in Figure 1, our conceptual framework calls for greater attention to the translation of international initiatives through policy processes at national and sub-national scales. This IDS Bulletin identifies a number of cross-cutting themes on this translation process that deserve further attention to improve understanding of the political economy of climate change and development.

The first theme concerns the relationship between the global and the national level. As in debates around development assistance, the question of ownership at the national level remains an important point of contention. This is illustrated by the dispute described in the article by Alam et al. between the Government of Bangladesh and international donors over the role of the World Bank in managing climate change trust funds. Support to the government position from the country's media and international NGO campaigners was chiefly over the principle of climate change funding being distinct from development cooperation, based on responsibility not charity. Shankland and Chambote's article on Mozambique provides another illustration on how international climate change initiatives are still largely top-down processes, characterised by contestation of an imposed agenda by the World Bank Group institutions rather than inclusion within processes of planning those initiatives. Examining India's clean energy sector, the Newell et al. article shows how both the perception and reality of a positive international investment climate means the Indian state is well placed to lever the private capital required to fund a low carbon energy transition.

The role of internationally renowned expertise in national processes also raises questions about country ownership and policy choices and preferences. Such actors blur the global-national divide, sometimes playing crucial roles in shaping agendas and priorities at both scales (Edwards and Miller 2001; Bäckstrand 2003). As the cases in Brazil and Bangladesh demonstrate, these countries have themselves been very important in shaping the international agenda. The relationship also cannot be limited to an understanding of a top-down process, since the ambiguity surrounding concepts such as adaptation, mitigation and resilience has led to different interpretations and outcomes in various countries. The confusion between these concepts is well illustrated in the Nepal case study by Ayers et al., where various stakeholders hold different interpretations and definitions according to their own political interest.

The second important line of enquiry in the political economy of climate change and development focuses on the link between power and ideologies. While a variety of ideologies and environmental worldviews have been identified by the different authors in this IDS Bulletin (see, e.g. Shankland and Hasenclever's definition of a sociocultural perspective by indigenous groups in Brazil), there is often a lack of clear leadership and significant levels of contestation on climate change issues. In many countries, it is unclear at the government level who is and should be responsible, whether the Ministry of Environment or the Ministry of Planning, with limited interest and involvement of the political parties (see, e.g. the article on Bangladesh by Alam et al.). The same issue dominates civil society organisations, which are often fragmented according to specific sectoral interests and issues. One can observe a crisis of leadership and vision in the environmental sector.

Third, institutional dynamics are often explained by path dependency rather than by clear leadership, ideologies and visions. In Mozambique, climate change policy is understood through the lens of disaster risk reduction and as a continuation of this paradigm. In Bangladesh, climate change has been interpreted as part of environmental management, with leadership on 
the national climate change plan, its finance and the PPCR process all directed through the Ministry of Environment and Forests.

However, the most striking feature in this IDS Bulletin on the political economy of climate change and development, is the sense of urgency that has dominated the national policy process in all the countries examined. This has resulted in issues around coordination with other initiatives, the level of participation, and time horizons. This sense of urgency can be explained due to the global discourse urging leaders to act quickly to provide policies to adapt and mitigate climate change, but also the growing association between disaster events with climate change. Articles here suggest that commonly rushed schedules for implementation, whether in Bangladesh, Brazil or Mozambique for example, did not foster the basis for a strong level of participation from across government, NGO and civil society. The responses by civil society organisations have also been slow in part due to sectoral divisions and the difficulty of voicing a unified message.

This urgency may also influence design criteria for initiatives, pushing them towards areas and interventions where they easily demonstrate short-term impact. We believe therefore that programmes such as the PPCR are therefore likely to channel money to areas where the additional element of 'climate proofing' is most readily discernible, perhaps favouring technological add-ons, rather than addressing the contextual factors related to development that determine vulnerability to climate change impacts. This in turn may limit the potential for any transformational changes as a result.

\subsection{Understanding and informing policy spaces for change}

The final set of articles brings the discussion back to the issue of how research inputs can inform policy processes around climate change and development. In investigating links between policy-focused and action researchers in climate adaptation, they examine the potential for action research to understand and explicitly link with relevant policy processes and spaces. Lars Otto Naess et al. provide an overview of this work, echoing our call for going beyond conventional governance analysis to incorporate wider influences on policy processes, including ideologies and narratives.
Working with participatory action research projects under the Climate Change Adaptation in Africa (CCAA) programme, they outline an analytical framework adapted from on research on environmental policy processes in Africa and on policy spaces in power analysis (Keeley and Scoones 2003; Gaventa 2006). This combines analysis of narratives and evidence, actors and networks, and politics and interests to study the different potential spaces and means for research to influence policy. In designing and informing adaptation initiatives, they call for greater attention to understanding the processes through which different policy pathways are chosen and implemented.

The importance of narratives in driving policy agendas is critical to the case studies presented. Narratives are storylines that help identify competing ways of viewing a particular policy problem. Broad narratives around climate change include one which suggests that climate change is a grave threat to humankind. An alternative narrative is that climate change presents opportunities for improving human wellbeing. Blessings Chinsinga et al.'s investigation into a crop diversification initiative in Malawi exposed conflicting government policies that undermine the potential contribution that such a project can make to adaptation. Dominant narratives equating food security with maize sufficiency at household and national level frustrated the ability of the research to demonstrate the value of crop diversification to policymakers. Although it underlies much of government agriculture policy, crop diversification is limited, as there are few mechanisms to ensure alternative crops are available for farmers. This narrative is strengthened by strongly ingrained perceptions of Malawians of alternative crops as 'inferior food'. The researchers find the 'crop diversification for adaptation' narrative to be much weaker, despite the investments in related research, and interventions such as the fertiliser subsidy programme.

Guthiga and Newsham's contribution reinforces the importance of strong narratives at national and sub-national scales. They argue that these narratives weaken the potential for indigenous knowledge (IK) to enter mainstream debates on adaptation and to be adequately represented in policy fora, despite growing international acceptance of the value of IK for adaptation 
(Tschakert 2007). Climate change as a futuristic concern may add to perception of indigenous practices as outdated and unreliable, and the validity of IK in general requires greater recognition at the national level before IK research can have significant influence. Their case study shows that although discrete observations from IK are increasingly recognised, this does not extend to the wider management systems, institutions and worldviews in which IK is embedded. This is of key importance to the knowledge systems' continued use in a changing climate.

Understanding the political economy of the policy process is important not only to improve policy impact of research but also because it can help to understand the dynamics and characteristics underpinning adaptive capacity and resilience. This in turn helps to determine what processes promote more robust and resilient societies in line with broader development challenges (Adger et al. 2007). By identifying policy spaces, the authors in this section argue that political economy analyses can be key considerations for improved success in policy engagement for adaptation research. This may include working with relevant actors and networks, understanding their interests and examining how research fits with dominant narratives. In some cases, this may mean challenging narratives and 'tinkering around the edges' to influence policies. However, this is not likely to be sufficient for the research evidence to have an impact on policies.

\section{A future agenda to challenge linear policy models and apolitical initiatives}

In summary, the growing importance of climate change in the development arena and the frequent assumption of linear policymaking and apolitical, techno-managerial solutions make the development of a new political economy emphasis vital to determining efficient, equitable and effective responses. Drawing on the articles in this IDS Bulletin, we suggest that explicit attention is given to the way that ideas, power and resources are conceptualised, negotiated and implemented by different groups at different scales. In particular, this is needed in the formulation of international initiatives and their translation to national and sub-national policy contexts. At the same time, there is a pressing need to better understand the role of academic and scientific research and data in these processes. An awareness of these underlying processes will help the wide range of people with a stake in climate and development futures to negotiate and implement changes that learn from mistakes and build on successes.

The political economy of climate change and development urgently needs further attention and research, particularly as financial flows for climate change and development are only recently beginning to have significance at national level. We have identified two important avenues for future research. First, the question of the perception of donors by recipient countries is clearly an important research area. In this IDS Bulletin, we have seen that most interventions are still designed through a donor-recipient relationship. These relationships ignore two major issues that are particularly relevant to climate change debates: (1) climate change programmes on mitigation and adaptation are part of a larger global political process which recognise responsibilities and rights and global justice around climate change issues, and (2) the beneficiaries of these interventions may be wider than the host country, extending to the global community. Further research therefore needs to examine more precisely to what extent are donor-recipient relationships changing in terms of design and implementation of climate change and development programmes? Second, as most of these international initiatives and programmes are at their early phases, it was too early to examine issues related to governance and institutional capacity, especially at the national level. Additional research is needed on the relationship between ideologies, power and resources to understand to what extent policy practices will be effective depending on the congruence between ideas and ideologies and power configurations. This includes understanding how the operationalisation of policy practices for climate change mirrors particular governance models (regulatory or market-based) that reflect particular dominant interests and ideas. 
Notes

* The publication of this issue of the IDS Bulletin was made possible through the support of the UK Department for International Development (DFID) through the Political Economy of Low Carbon Climate Resilient Development project. We gratefully

\section{References}

Abdullah, A.; Muyungi, R.; Jallow, B.; Reazuddin, M. and Konate, M. (2009) National Adaptation Funding: Ways Forward for the Poorest Countries, IIED Briefing Paper, London: International Institute for Environment and Development

Adger, W.N.; Paavola, Y.; Huq, S. and Mace, M.J. (2006) Fairness in Adaptation to Climate Change, Cambridge, MA: MIT Press

Adger, W.N.; Agrawala, S.; Mirza, M.M.Q.; Conde, C.; O'Brien, K.; Pulhin, J.; Pulwarty, R.; Smit, B. and Takahashi, K. (2007) 'Assessment of Adaptation Practices, Options, Constraints and Capacity', in M.L. Parry, O.F. Canziani, J.P. Palutikof, P.J. van der Linden and C.E. Hanson (eds), Climate Change 2007: Impacts, Adaptation and Vulnerability. Contribution of Working Group II to the Fourth Assessment Report of the Intergovernmental Panel on Climate Change, Cambridge: Cambridge University Press

AfDB (African Development Bank); Asian Development Bank; Department for International Development; DirectorateGeneral for International Cooperation: the Netherlands; Directorate General for Development: European Commission; Federal Ministry for Economic Cooperation and Development: Germany; Organisation for Economic Co-operation and Development; United Nations Development Programme; United Nations Environment Programme; World Bank (2003) Poverty and Climate Change: Reducing the Vulnerability of the Poor Through Adaptation, Washington DC: World Bank, http://ec.europa.eu/development/icenter/ repository/env_cc_varg_poverty_and_climate_ change_en.pdf (accessed 18 January 2011)

Aronson, J.; Harré, R. and Cornell Way, E. (1994) Realism Rescued: How Scientific Progress is Possible, London: Duckworth

Bäckstrand, K. (2003) 'Civic Science for Sustainability: Reframing the Role of Experts, Policy-Makers and Citizens in Environmental Governance', Global Environmental Politics 3.4: 24-41 acknowledge the support of Andrew Clayton, Kirsty Mason, Jane Clark, Rita Zacarias, Simon Lucas, Clare Shakya and Dan Bradley. The views expressed in this and all other articles in this IDS Bulletin are the views of the authors alone and do not represent the views or policies of IDS, DFID, or the UK government.

Barnett, M. and Duvall, R. (eds) (2005) Power in Global Governance, Cambridge: Cambridge University Press

Barnett, M.N. and Finnemore, M. (2004) Rules for the World: International Organizations in Global Politics, New York: Cornell University Press

Béland, D. (2009) 'Ideas, Institutions, and Policy Change', Journal of European Public Policy 16.5: 701-18

Bernstein, S. (2001) The Compromise of Liberal Environmentalism, New York: Columbia University Press

Bird, N.; Brown, J. and Schalatek, L. (2011) Design Challenges for the Green Climate Fund, ODI/Heinrich Böll Foundation Climate Finance Policy Brief 4, London: Overseas Development Institute

Bourdieu, P. (1977) Outline of a Theory of Practice, Cambridge: Cambridge University Press

Bryant, R. and Bailey, S. (1997) Third World Political Ecology, London: Routledge

Cammack, D. (2007) 'Understanding the Political Economy of Climate Change is Vital to Tackling It', Opinion 92, London: Overseas Development Institute

Campbell, J.L. (1998) 'Institutional Analysis and the Role of Ideas in Political Economy', Theory and Society 27: 377-409

Carvalho, A. (2007) 'Ideological Cultures and Media Discourses on Scientific Knowledge: Re-reading News on Climate Change', Public Understanding of Science 16.2: 223-43

Clapp, J. and Dauvergne. P. (2005) Paths to a Green World: The Political Economy of the Environment, Cambridge, MA: MIT Press

Dessler, A.E. and Parson, E.A. (2006) The Science and Politics of Global Climate Change: A Guide to the Debate, Cambridge: Cambridge University Press

DFID (2009) Political Economy Analysis: How to Note, DFID Practice Paper, London: Department for International Development, www.gsdrc.org/docs/open/PO58.pdf (accessed 10 February 2011)

Edwards, P. and Miller, C. (eds) (2001) Changing the Atmosphere: Expert Knowledge and Global 
Environmental Governance, Cambridge, MA: MIT Press

European Commission (2008), 'Analysing Sector Governance', Chapter 4 in Addressing Governance in Sector Operations, EC Sector Reference Document

Gaventa, J. (2006) 'Finding the Spaces for Change: A Power Analysis', IDS Bulletin 37.6: 23-33

GHF (2009) Human Impact Report: Climate Change - The Anatomy of a Silent Crisis, Geneva: Global Humanitarian Forum

IEA/UNDP/UNIDO (2010) Energy Poverty: How to Make Modern Energy Access Universal?, special early excerpt of the World Energy Outlook 2010 for the UN General Assembly on the Millennium Development Goals, Paris: OECD/IEA

Jamieson, D. (2001) 'Climate Change and Global Environmental Justice', in P. Edwards and C. Miller (ed.), Changing the Atmosphere: Expert Knowledge and Global Environmental Governance, Cambridge, MA: MIT Press

Kates, R. (2000) 'Cautionary Tales: Adaptation and the Global Poor', Climatic Change 45.1: 5-17

Keeley, J. and Scoones, I. (2003) Understanding Environmental Policy Processes: Cases from Africa, London: Earthscan

Klein, R.T.J.; Eriksen, S.E.H.; Næss, L.O.; Hammill, A.; Tanner, T.M.; Robledo, C. and O'Brien, K.L. (2007) 'Portfolio Screening to Support the Mainstreaming of Adaptation to Climate Change into Development Assistance', Climatic Change 84.1: 23-44

LaFleur, V.; Purvis, N. and Jones, A. (2008) Double Jeopardy: What the Climate Crisis Means for the Poor, Brookings Blum Roundtable 2008, Washington DC: Brookings Institution

Leach, M.; Scoones, I. and Stirling, A. (2010), Dynamic Sustainabilities - Technology, Environment, Social Justice, London: Earthscan

Levy, D.L. and Kolk, A. (2002) 'Strategic Responses to Global Climate Change: Conflicting Pressures on Multinationals in the Oil Industry', Business and Politics 4.3, Article 2

Levy, D.L. and Newell, P.J. (2002) 'Business Strategy and International Environmental Governance: Toward a Neo-Gramscian Synthesis', Global Environmental Politics 2.4: 84-101

Luterbacher, U. and Sprinz, D.F. (eds) (2001) International Relations and Global Climate Change, Cambridge, MA: MIT Press

McCarthy, J.; Canziani, O.F.; Leary, N.A.; Dokken, D.J. and White, K.S. (eds) (2001) Climate
Change 2001: Impacts, Adaptation and Vulnerability, Cambridge: Cambridge University Press

McGray, H.; Bradley, R. and Hammill, A. (2007) Weathering the Storm: Options for Framing Adaptation and Development, Washington DC: World Resources Institute, http://pdf.wri.org/ weathering_the_storm.pdf (accessed 15 February 2011)

Nabuurs, G.J.; Masera, O.; Andrasko, K.; Benitez-Ponce, P.; Boer, R.; Dutschke, M.; Elsiddig, E.; Ford-Robertson, J.; Frumhoff, P.; Karjalainen, T.; Krankina, O.; Kurz, W.A.; Matsumoto, M.; Oyhantcabal, W.;

Ravindranath, N.H.; Sanz Sanchez, M.J. and Zhang, X. (2007) 'Forestry', in B. Metz, O.R. Davidson, P.R. Bosch, R. Dave, L.A. Meyer (eds), Mitigation of Climate Change, Contribution of Working Group III to the Fourth Assessment Report of the Intergovernmental Panel on Climate Change, Cambridge: Cambridge University Press Newell, P.J. and Paterson, M. (2010) Climate Capitalism: Global Warming and the Transformation of the Global Economy, Cambridge: Cambridge University Press

OECD (2009) Policy Guidance on Integrating Climate Change Adaptation into Development Co-operation, Paris: Organisation for Economic Co-operation and Development

Okereke, C. (2008a) Global Justice and Neoliberal Environment Governance: Ethics, Sustainable Development and International Co-operation, Abingdon: Routledge

Okereke, C. (2008b) 'Equity Norms in Global Environmental Governance', Global Environmental Politics 8.3: 25-50

Oxfam (2009a) Suffering the Science: Climate Change, People, and Poverty, Oxfam Briefing Paper 130, Oxford: Oxfam

Oxfam (2009b) Beyond Aid: Ensuring Adaptation to Climate Change Works for the Poor, Oxfam Briefing Paper 132, Oxford: Oxfam

Park, J.; Conca, K. and Finger, M. (2008) The Crisis of Global Environmental Governance: Towards a New Political Economy of Sustainability, Abingdon: Routledge

Rabe, B.G. (2007) 'Beyond Kyoto: Climate Change Policy in Multilevel Governance Systems', Governance: An International Journal of Policy, Administration, and Institutions 20.3: 423-44

Reid, H.; Huq, S. and Murray, L. (2003) Mainstreaming Adaptation to Climate Change in Least Developed Countries, London: International Institute for Environment and Development 
Roberts, J.T. and Parks B.C. (2007) A Climate of Injustice: Global Inequality, North-South Politics and Climate Policy, Cambridge, MA: MIT Press

Schneider, S.H. (2010) 'The Politics of Climate Science', in M. Boykoff (ed.), The Politics of Climate Change, Abingdon: Routledge

Sida (2006) Power Analysis - Experiences and Challenges, Stockholm: Swedish International Development Cooperation Agency

Smith, P.; Martino, D.; Cai, Z.; Gwary, D.; Janzen, H.; Kumar, P.; McCarl, B.; Ogle, S.; O'Mara, F.; Rice, C.; Scholes, B. and Sirotenko, O. (2007) 'Agriculture', in B. Metz, O.R. Davidson, P.R. Bosch, R. Dave, L.A. Meyer (eds), Mitigation Climate Change, Contribution of Working Group III to the Fourth Assessment Report of the Intergovernmental Panel on Climate Change, Cambridge: Cambridge University Press

Stern, N. (2006) The Economics of Climate Change: The Stern Review, Cambridge: Cambridge University Press

Strange, S. (1988) States and Markets, London: Pinter Publishers

Tanner, T.M. and Mitchell, T. (eds) (2008) 'Poverty in a Changing Climate', IDS Bulletin 39.4
Tol, R.S.J.; Downing, T.E.; Kuik, O.J. and Smith, J.B. (2004) 'Distributional Aspects of Climate Change Impacts', Global Environmental Change 14: 259-72

Tschakert, P. (2007) 'Views from the Vulnerable: Understanding Climatic and Other Stressors in the Sahel', Global Environmental Change 17: 381-96

UNDP (2007) Human Development Report 2007/2008 Fighting Climate Change: Human Solidarity in a Divided World, New York: United Nations Development Programme

UN-Energy (2010) Delivering on Energy: An Overview of Activities by UN-Energy and its Members, New York: UN-Energy

World Bank (2009) Problem-Driven Governance and Political Economy Analysis: Good Practice Framework, Washington DC: World Bank World Bank (2004) Operationalizing Political Analysis: The Expected Utility Stakeholder Model and Governance Reforms, PREM Notes 95, Washington DC: World Bank

Yamin, F. and Depledge, J. (2004) The International Climate Change Regime: A Guide to Rules, Institutions and Procedures, Cambridge: Cambridge University Press 